Check for updates

1 Centre for Occupational and Environmental Health, Ellen Wilkinson Building, University of Manchester, Manchester M13 9PL, UK

2 Beatson West of Scotland Cancer Centre, Gartnavel Hospital, Glasgow, UK

3 University of Nottingham, Nottingham, UK

4 De Montfort University, Leicester, UK

rmagius@doctors.org.uk

Cite this as: BMJ 2021;373:n950 http://dx.doi.org/10.1136/bmj.n950 Published: 13 April 2021
COVID-19: ASSESSING RISK FOR HEALTHCARE WORKERS

\section{Assessing risk for healthcare workers during the pandemic: don't forget workplace safety committees or airborne transmission}

\author{
Raymond M Agius, ${ }^{1}$ Lewis T Hughes, ${ }^{2}$ Denise Kendrick, ${ }^{3}$ John F R Robertson, ${ }^{3}$ Marcia Stewart ${ }^{4}$
}

Khunti and colleagues advocate integrating "the workplace, the workforce, and the individual" in "assessing risk for healthcare workers during the covid-19 pandemic." ${ }^{1}$ The same approach is relevant to other workers, notably in social care. It also warrants highlighting that health and safety law requires a "suitable and sufficient" risk assessment and the involvement of workers and their representatives. $^{2}$

The pandemic ought to encourage active and effective safety committees and safety representatives in all workplaces since they can make valuable contributions to risk assessment. These committees and representatives are legally mandated with provisions made for activities to be undertaken during paid time. ${ }^{3}$ Such collective representative mechanisms offer an essential counterweight to the imbalance of power which exists between employees and employers. This is particularly important when the balance of power in organisations does not necessarily favour the most vulnerable, as with ethnic minority colleagues in the NHS or the poorly paid.

The article refers to aerosol generating procedures (AGP). This term implies that those procedures are the main source of viral aerosol to which healthcare workers are exposed, contradicting the evidence. ${ }^{4}$ Worse still for healthcare workers, AGP is often considered to the exclusion of other procedures or even processes such as coughing or speaking ${ }^{5}$ which are then not mitigated against. ${ }^{6}$ The concept of AGP has limited applicability in practice and probably represents little more than early attempts to "rationalise the rationing" of protective measures and ignores important lessons about worker protection. ${ }^{7}$ Those in workplaces such as general practice can be exposed to viral aerosols, even if not engaged in AGP. ${ }^{8}$ All workers encountering such exposure must have a sufficient workplace assessment and appropriate risk reduction such as through better ventilation and filtering face piece respirators. ${ }^{9}$

Competing interests: None declared.

Khunti K, Griffiths A, Majeed A, Nagpaul C, Rao M. Assessing risk for healthcare workers during the covid-19 pandemic. BMJ2021;372:n602. doi: 10.1136/bmi.n602 pmid: 33722904

2 Health and Safety Executive. What the law says on assessing risks. www.hse.gov.uk/managing/delivering/do/profiling/the-law.htm

3 Safety Representatives and Safety Committees Regulations 1977. www.legislation.gov.uk/uksi/1977/500/contents/made

4 Lewis D. Mounting evidence suggests coronavirus is airborne - but health advice has not caught up. Nature 2020;583:510-3. www.nature.com/articles/d41586-020-02058-1.

doi: 10.1038/d41586-020-02058-1 pmid: 32647382
5 Morawska L, Milton DK. It is time to address airborne transmission of coronavirus disease 2019 (covid-19). Clin Infect Dis 2020;71:2311-3. doi: 10.1093/cid/ciaa939 pmid: 32628269

6 Wilson N, Corbett S, Tovey E. Airborne transmission of covid-19. BMJ 2020;370:m3206. doi: 10.1136/bmj.m3206 pmid: 32819961

7 Agius RM, MacDermott N. Covid-19 and workers' protection: lessons to learn, and lessons overlooked. Occupational Medicine. $2021 \mathrm{Mar}$ 18;kqab034. https://academic.oup.com/occmed/advance-article/doi/10.1093/occmed/kqab034/6176307

8 Kendrick D, Agius RM, Robertson JFR, Sewell HF, Stewart M. Was enough, and is enough, being done to protect the primary care workforce from COVID-19?Br J Gen Pract 2021;71:100-1. doi: 10.3399/bjgp21X714953 pmid: 33619047

9 Agius RM, Kendrick D, Sewell HF, Stewart M, Robertson JF. Reaffirming health and safety precautionary principles for COVID-19 in the UK. Lancet 2021;397:274. doi: 10.1016/S0140-6736(21)00088-X pmid: 33485442

This article is made freely available for use in accordance with BMJ's website terms and conditions for the duration of the covid-19 pandemic or until otherwise determined by BMJ. You may use, download and print the article for any lawful, non-commercial purpose (including text and data mining) provided that all copyright notices and trade marks are retained. 